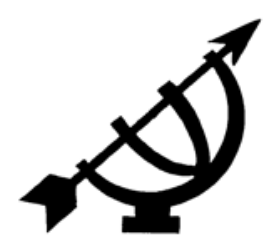

\title{
Using reflexive photography to study a principal's experiences of the impact of professional development on a school: a case study
}

\author{
G.M. Steyn
}

Department of Further Teacher Education

University of South Africa

PRETORIA

E-mail: steyngm1@unisa.ac.za

\begin{abstract}
Using reflexive photography to study a principal's experiences of the impact of professional development on a school: a case study

The changing social and economic environment has a direct impact on schools and their effective management. School principals have to deal with issues hitherto unknown to them in historical school cultures. This article attempts to describe a South African principal's experience of the way in which professional development (PD) impacted on the development of the school and the way in which his PD - and that of his staff manifests itself in the functioning of the school. An exploratory qualitative study employing visual ethnography was deemed appropriate for the study. Convenient and selective sampling was used in the study, identifying a school principal who proved to be an exemplar of a principal placing a high premium on his own continuing professional development and that of others. Data were collected by means of reflexive photography, the principal's writings and a photo-elicitation interview. The following categories emerged from the data: the commitment and attitude of the principal to professional development; the head start: receiving the inviting school award; be positive $(B+)$; a focus on client service (doing more than is expected; the blue and orange card system for learners; and inculcating a value system); and what do we do differently?
\end{abstract}




\section{Opsomming}

\section{Die gebruik van refleksiewe fotografie om 'n skoolhoof se ervarings van die impak van professionele ontwikkeling te bestudeer: 'n gevallestudie}

Die veranderde sosiale en ekonomiese omgewing het 'n direkte impak op skole en die effektiewe bestuur daarvan. Vir skoolhoofde is dit nodig om onbekende kwessies te hanteer. Hierdie artikel poog om 'n Suid-Afrikaanse skoolhoof se ervarings van die wyse waarop professionele ontwikkeling die ontwikkeling van die skool en dié van personeel in die funksionering van die skool beïnvloed het, te bestudeer. 'n Verkennende, kwalitatiewe studie deur middel van visuele etnografie is vir die studie geskik gevind. Gerieflike en selektiewe steekproefneming is gedoen om 'n skoolhoof te identifiseer wat as voorbeeld kon dien van 'n skoolhoof wat 'n hoë premie plaas op sy/haar eie en ander se voortgesette professionele ontwikkeling. Data is deur middel van refleksiewe fotografie, die skoolhoof se skrywes, sowel as 'n foto-verduidelikende onderhoud ingesamel. Die volgende kategorieë het uit die data na vore gekom: 'n toegewyde en positiewe gesindheid van die skoolhoof teenoor professionele ontwikkeling; die voorsprong: ontvangs van die uitnodigende skooltoekenning; wees positief (B+); 'n fokus op kliëntediens (doen meer as wat verlang word; die blou-en-oranjekaartstelsel vir leerders; die vaslegging van waardes); en wat doen ons anders?

\section{Introduction}

Principals and educators are facing tough and challenging times in working effectively in schools (Fennell, 2005:145; Hess \& Kelly, 2005:2; Rodrigues-Campos et al., 2005:309; Vick, 2004:10). Moreover, numerous impassioned calls for school improvement escalated inside and outside schools (Darling-Hammond \& Richardson, 2009; Levine, 2005:68; Southworth \& Du Quesnay, 2005:219). Varying expectations of role-players arising from the substantial changes in the management and acquisition of knowledge, changes in human interaction and the composition of families all contribute to extreme pressures on schools to perform better. If the focus is on the improvement of schools, principals need to play a key role in these improvements (Donaldson, 2009; Houle, 2006; Mestry \& Grobler, 2004; Vick, 2004). Many studies confirm the importance of leadership in the development and improvement of organisations (Chappuis et al., 2009; Olivier \& Hipp, 2006). 
The role of principals has undergone rapid change (Cardno, 2005; Graczewski \& Holtzman, 2009; Houle, 2006; Kinney, 2009) and they should possess certain leadership abilities in order to achieve and maintain quality schools in complex environments (Donaldson, 2009; Rodrigues-Campos et al., 2005; Vick, 2004). It is also important for principals to understand leadership as a process and to develop the necessary human relation skills to promote joint action and ensure an improvement in school effectiveness and student learning (Jabal, 2006; McClay \& Brown, 2003). Elaborating on this view, Houle (2006:145) asserts: "The tension created in shifting views on the principals requires attention to the professional development (PD) needs of principals in the light of their new roles." A focus on the professional development of leaders is also crucial to the delivery of education across schools (Cardno, 2005). Furthermore, this emphasises the fact that professional abilities require "rich, continual performance in which to grow" (Donaldson, 2009).

According to Mestry and Grobler (2004:3), education management development should be seen as a process whereby individual development and the achievement of organisational goals need to be synchronised. The individual's management development is placed within the school context and becomes a fundamental part of the daily management of schools (Mestry \& Grobler, 2004; McClay \& Brown, 2003). The process of development is mainly concerned with equipping principals to acquire and improve the necessary competencies to manage their schools effectively. This is in line with a literature survey between 1990 and 2001 by Gonzales et al. (2002) which found that 125 studies described the relationships between leadership practices and achievement. In this study, 60 of the studies provided evidence of the influence of leadership on student achievement. Similarly Cardno (2005:293) believes that one "aspect of leadership in its broadest sense is the capacity of key individuals to exert influence that results in positive change for the school ... and ultimately for the benefit of students". However, it is necessary to know that the link between principals' professional development and improved school performance is complex and very dynamic (Donaldson, 2009). Nevertheless, it is important to indicate how a principal as a key individual can impact the development of a school for the benefit of students.

The Urban Principals' Academy (UPA) addresses three areas of principals' professional development: instructional leadership, capacity building and personal renewal (Houle, 2006:150). As regards 
the latter area, principals who attend to themselves as individuals also acknowledge the fact that their professional authenticity is closely linked to their self-efficacy (Houle, 2006). This is confirmed by Hoy and Smith (2007:160) who assert, "leaders with high selfefficacy in their ability to influence others are likely to be effective in that endeavour". For principals to lead effectively, they require a great deal of interpersonal learning to help them understand how principals' "words, behaviours and moods are shaped by those of the people" they attempt to lead (Donaldson, 2009:16). Moreover, school leadership develops over an extended period of time that also includes complex processes of socialisation (Weindling, 2003).

It is widely known that principals in South Africa have a huge task to create an effective learning environment in schools (Mestry \& Grobler, 2004:2). In this regard Bloch (2008:19) and Paton (2006:1) state that South African schools do not meet the requirements for a developing country - they are recognised to be in crisis and in a state of disaster. Although there are some empirical evidence regarding the impact of professional development programmes on school leaders, sustained studies on the impact of leadership development are not visible in the literature (Brundrett, 2000). This article attempts to describe a South African principal's experience of the way in which his PD - and that of his staff - impacted the development of the school and manifests itself in the functioning of the school.

\section{Theoretical framework}

Both constructive development theories and adult learning theories are used in the study to understand adult development and growth (Drago-Severson, 2007). Adults bring their life and work experiences, needs, personalities and learning styles to learning and these also influence their views on learning and PD (Drago-Severson, 2007; Knowles, 1984). The andragogy theory of Knowles is an attempt to develop a theory in particular for adult learning. Knowles (1984) puts emphasis on adults who are self-directed and expect to take responsibility for decisions. Andragogy makes the following assumptions about learning: adults want to know why they need to learn something; adults need to learn through experience; adults learn best when the topic is of immediate significance and value; and adults approach their learning as problem-solving. Hirsh (2005) and Lee (2005) are of the opinion that the beliefs and assumptions regarding adult learning need to form the foundation of PD programmes. 
As regard constructive-development theories, this paper focuses primarily on the social constructive theory that is used as a lens through which to view how a principal's meaning system shapes the learning challenges he faces (Drago-Severson, 2007:80). According to this view an individual (the principal) searches for an understanding of the world in which he/she lives and works (Creswell, 2007:20). The individual develops subjective meanings of his/her experiences which are varied and multiple (Creswell, 2007:20). The aim of such a study is therefore to rely predominantly on a participant's view of a particular phenomenon, in this case PD. Social constructivism also illuminates developmental foundations of the principal's practice and the interaction between the principal's developmental capacity and his engagement in school practice. According to social constructivist learning theories, learning is constructive and learners construct and build new conceptualisations and understandings by using what they already know (Chalmers \& Keown, 2006; Mahoney, 2003). Its impact is manifested within a specific environment, in this case a primary school in Gauteng, South Africa.

In the light of the above, PD can therefore be operationalised by means of constructivist approaches which recognise the following (Chalmers \& Keown, 2006; Darling-Hammond \& Richardson, 2009; Paavola et al., 2004; Wenger, 2007; Hodkinson \& Hodkinson, 2005):

\section{- $\quad$ The constructed meaning of knowledge and beliefs}

This is a process whereby an individual discovers new knowledge, skills and approaches and then personally interprets their significance and meaning.

\section{- $\quad$ The situated nature of cognition}

This aspect recognises the fact that PD has to be strongly linked to the actual contexts and situations of the individual school. This is also in line with Engestrom's (1987) model of expansive learning which postulates that human beings do not live in a vacuum, but are embedded in their sociocultural context (Paavola et al., 2004), and their behaviour cannot be comprehended independently of this context.

\section{- $\quad$ The importance of ample time}

New developments and change take time to be implemented. 
There is a need for practices informed by constructivist theories about how PD can positively impact schools. This study also illuminates how principals can play a key role within their school contexts.

\section{The key role of principals}

School principals play a key role in creating and maintaining effective school environments for the sake of student performance (Cardno, 2005; Chappuis et al., 2009; Hale \& Moorman, 2003; Hammersley-Fletcher \& Brundrett, 2005; Lin, 2005; Olivier \& Hipp, 2006; Vick, 2004). Principals also act as lynchpins facilitating change and creating an effective learning environment in schools (McClay \& Brown, 2003; Van der Merwe, 2003; Southworth \& Du Quesnay, 2005), such as is the case with inviting schools (Egley, 2003). It means that their leadership may have an impact on relationships and outcomes within the school (Berry, 2004). Facilitating learning for individual school leaders as well as the members of organisations is viewed as the primary goal of leadership (Amey, 2005). When conceptualising leadership as learning, the objective is to uncover mental models that affect the way in which educational leaders view the world and act within their contexts (Amey, 2005).

Wegenke (2000) believes that continuing PD for principals is necessary in order to maintain a positive school environment. Through their PD principals can influence the school's effectiveness by encouraging a culture of renewal and change (Rodrigues-Campos et al., 2005). PD is an "effective way for principals to gain new knowledge, develop new skills, and model self-renewal" (RodriguesCampos et al., 2005:312). According to Benjamin (as quoted in Kent, 2002:214) there are four objectives for leadership development: to develop individual leadership effectiveness, to improve career transition into leadership positions, to instil the vision, values and mission of the organisation, and to develop knowledge and skills to implement the long-term strategic objectives of the organisation.

Transformational forms of leadership fundamentally aim to make events meaningful and to cultivate professional development and higher levels of commitment to organisational goals ( $\mathrm{Yu}$ et al., 2000). These include:

- Identifying and sharing a vision (Hoy \& Smith, 2007; Kassissieh \& Barton, 2009; Sternberg, 2005; Vick, 2004). The first characteristic of effective educational leaders is their ability to align vision and personal, professional and organisational values with 
the particular context in the school (Jabal, 2006; Hoy \& Smith, 2007; Kassissieh \& Barton, 2009). Charisma is a characteristic of leaders who are able to exert a profound influence on the school's performance and climate by the force of their personality, abilities, personal charm, magnetism, inspiration and emotion (Sternberg, 2005; Vick, 2004).

- Offering intellectual stimulation. Such stimulation creates a gap between the current and desired practices and could enhance emotional arousal processes (Kassissieh \& Barton, 2009).

- Setting an appropriate example. Through active involvement in continuing PD, principals set examples for staff to follow (Chappuis et al., 2009; Rodrigues-Campos et al., 2005; Southworth \& Du Quesnay, 2005). The school leader's role is "grounded in shared ideals where the leaders serve as the head follower by modelling, teaching, and helping others to become better followers" (McKerrow et al., 2003:2). Furthermore, by doing so principals also set an example for staff and learners to continue their own learning. Staff should also be convinced about the expertise of their principals (Hoy \& Smith, 2007).

- A positive attitude and commitment to development. Studies consistently show the importance of attitudes and commitment to ensure effective development and change (Dell, 2003; Gray, 2005). However, Bernat (2000) maintains that, while it is not easy for attitudes to change, it is necessary that they change before any meaningful and permanent learning can take place. This is in line with Ottoson's view expressed in Smith and Gillespie (2007). Ottoson believes that pre-existing attitudes are among the factors that can affect the implementation of training and development.

- Strengthening school culture. Principals set the climate and tone of schools: they influence the overall culture of schools (Cardno, 2005; Chappuis et al., 2009). Invitational Education (IE) as an example of a positive school culture, aims to "make school a more exciting, satisfying, and enriching experience for everyone - all students, all staff, all visitors" (Purkey \& Novak, 2008:19). Certain key assumptions that underpin IE are intended to foster the development of human potential. These assumptions are the following (Kok \& Van der Merwe, 2002; Novak \& Purkey, 2001; Purkey \& Siegel, 2003):

- Respect: this assumption acknowledges that every person is an individual of worth (Day et al., 2001). It also supports the 
principle that all individuals are able, valuable and responsible and that they should be treated accordingly.

- Optimism: people possess untapped potential for development and growth (Day et al., 2001).

- Trust: it is essential for education to involve everyone to promote empowerment and interdependency.

- Intention: it is an intentional decision to act in a particular way and to achieve and carry out a set goal (Day et al., 2001).

In her exploratory study on principals' perceptions of their experiences and the impact of their effectiveness, Berry (2004) identified positive experiences and also insights principals gained. In another study by Reeves et al. (1998) they indicate two interlinked aspects of learning to change practices:

- Internalisation: this refers to the personal sense individuals make of a concept or system of concepts linked to reflection (Lease, 2002). It also refers to the way in which individuals build experiences into their understanding of the concept as part of their professional knowledge.

- Externalisation: this refers to the process whereby individuals in their interaction with others use the new concepts or system of concepts to mediate their individual and joint practice (Olivier \& Hipp, 2006; Chappuis et al., 2009). It is also related to individuals' belief that the application of concepts or systems of concepts may bring about change in their working environment.

\section{Research design}

An exploratory qualitative study employing visual ethnography was deemed appropriate to determine the principal's experiences of the impact of PD within his school. A case study design helped the researcher to get a better understanding of the phenomenon (the impact of PD) in its natural setting with an emphasis on the experiences of the principal regarding the impact of PD (Creswell, 2007; Meadows, 2003). As such it involved the exploration and description of a bounded system, in this case a particular primary school in Gauteng (Creswell, 2007:73). In recent years, visual empirical methods have been applied to many studies that have not previously been considered to be visual (Denzin \& Lincoln, 2008; Harper, 2008; Schulze, 2007; Zenkov \& Harmon, 2009). Furthermore, visual empirical methods help with retrospection of lived 
experiences of participants and, by combining photographs with other forms of data collection, ensure contextual validity through triangulation. Atkinson and Delamont (2008) believe that there are numerous social phenomena that can be captured visually and analysed in terms of their manifestations. However, a particular social phenomenon should not be separated from the social setting in which it is generated and interpreted - a rule which was also adhered to in this study.

\subsection{Sample}

Convenient and selective sampling was used in the study. The author has been involved in a number of previous studies in the school since 1992 (Steyn, 1994; 2006; 2007; 2008; 2009). This status also earned me the principal's trust. During these studies the participant in the study proved to be an exemplar of a principal, placing a high premium on his own and others' continuing, professional development.

The importance of the principal's own PD for the development of the staff and school was described in Steyn (2006) where he specifically mentioned the effect of a professional development programme that explained and further confirmed his commitment to PD as follows:

The first law: 'The law of the lid', in The 21 laws of leadership by Maxwell actually gave me a wake-up call because I realised that if I did not develop and grow then my school wouldn't either. (Steyn, 2006:5.)

Previously the principal acknowledged the importance of PD, but did not realise the effect that his own PD could have on the PD of staff and also the development of the school. He has since then placed such a focus on PD that he postponed his retirement in order to develop the staff and the school.

The school is an urban, Afrikaans primary school with approximately 1400 learners and 80 staff members (administrative and academic). It is located in a middle-class community of affluent families, and $8 \%$ of the learners are exempted from school fees.

When participants interpret photographs they uncover their subjective meanings (Schulze, 2007) and these photos also assist the researcher to understand the participants' subjective experiences of relevant social concerns (Zenkov \& Harmon, 2009). The significant advantage of using photographs in the study is to clarify under- 
standing of the phenomenon, the impact of $P D$, and to provide a context in discussion with the participant.

\subsection{Data collection}

Denzin and Lincoln (1994) identify two distinct ways in which photography is used in qualitative research, namely as images generated by researchers and as images generated by participants. Following a "photo walk" introduction to the study and instructions for the use of the camera (Zenkov \& Harmon, 2009:577), the principal of a primary school in Gauteng was requested to take at least twenty pictures using the researcher's camera to illustrate the manifestation and impact of PD in his school. After a week he produced reflexive photographs as part of the data collection, described the photos in paragraph-length writings (Zenkov \& Harmon, 2009) and participated in a photo-elicitation interview (Harrington \& Schibik, 2003; Harper, 2008). He also provided a DVD, "In Hennops se voetspore die kaalvoet-pret-prestasieskool" (In Hennops's footsteps - the barefoot-fun-achievement school) that explains all the recent developments in the school. After listening to the DVD the information on it was transcribed. By using qualitative reflexive photography, the principal's writings, the DVD and the photo-elicitation interview, the researcher attempted to examine the principal's perceptions of the impact of PD in the school. The photo-elicitation interview specifically provided additional insight into the intrinsic meaning in the photographs. The idea is to evoke comments and discussion, since the principal can describe his own experiences via photographs and interviews (Schulze, 2007). The study explores two questions: How does the principal perceive the impact of professional development on the school? What role has the principal played in the manifestation of PD in the school?

As in previous studies at the school, the principal gave his informed consent to participate in the study. He agreed to take the photographs and to participate in a semi-structured photo-elicitation interview after the photos had been developed by the researcher. The day after the principal took the required number of photos, they were processed and the interview was conducted the following day. Permission was granted to record the interview. The interview was conducted in Afrikaans in the natural setting of the school (the principal's office) and it was transcribed verbatim. The quotations from the photo-elicitation interview used in this study were translated according to the original transcription and paragraph writings of the principal. Member checking was done by giving the principal a copy 
of the draft article with the findings of the study. The principal agreed with the findings, but elaborated on certain aspects in the findings.

The following serve as examples of questions developed for the photo-elicitation interview: Which photos best reveal the impact of PD on the school? Why have you chosen these photos? How do the photos reflect your attitude to PD? How do you see the role of the principal in PD? What guidelines do you suggest for principals who are implementing PD in schools?

\subsection{Analysis of data}

The transcribed verbatim data of the photo-elicitation interview, the DVD and the principal's writings were analysed. The following categories emerged from the data: the commitment and positive attitude of the principal to professional development; the head start: receiving the inviting school award; be positive $(B+)$; a focus on client service (doing more than is expected, the blue and orange card system for learners, and inculcating a value system); and What do we do differently?

\section{Findings}

Professional development is a continuous process in the school. On Wednesdays the school management team meets to identify and positively plan new innovations at the school. They also budget for PD programmes. Suitable non-departmental programmes are identified and the school selects staff in critical areas to attend workshops and seminars. On their return, participants have to convey what they learnt to the rest of the staff. The school only has an administrative meeting in the first term, while the rest of the terms are dedicated to development.

In the photo-elicitation interview it was clear that the principal placed a high premium on his commitment and attitude towards PD. On the question of which photos best exemplify the manifestation of PD in the school, he admitted that it was difficult, but he nevertheless chose three photos: the one on invitational education, the "be positive" sign and the tea tray (client service).

\subsection{The commitment and attitude of the principal to professional development}

Responding to the question of how the photos explain the principal's commitment to PD, he said: "Growth begins with the manager, and 
we [the school] cannot go without it [growth]." About six years ago he realised that he would be retiring and that he should further empower and develop his staff. He read John Maxwell's 21 laws of leadership. The first law, "The law of the lid", explicitly states that if you are a 4/10 leader, the organisation to which you belong will only be a 4. "If you do not grow, you will create a ceiling." He began to grow with the staff, and aggressively made an effort to attend courses of world standard. On certain days during the school term the school even have two staff development sessions. The school also budgets for courses, as he said - "not departmental". In addition, the principal selects staff in critical areas to attend appropriate courses. On their return, they present the programme to the rest of the staff. The current timetable also allows for staff development during the last week or two of a term. The majority of staff meetings are in the form of staff development sessions. This is the "way we can survive and function well" as a school, he commented.

On the question of how the photos reveal the principal's attitude to PD he said: "This is very difficult. A number of factors are involved." He referred to the famous story of people who came to a pastor and enquired about the congregation. They were interested in joining the church and wanted to know how things were going in the church. "Where we come from people complain about the pastor and they quarrel." The pastor said that this happened there too. After another year other people came and were searching for a church to join. They said, "We are so happy where we come from. The people work well together; they support each other." "It's the same here," the pastor said. What he actually wanted to say was, "It is attitude. It is something you carry with you ... If you are negative, you'll be negative in your work, your church, your country. You'll complain about everything."

The commitment and attitude of leaders to their own and others' PD is also supported in the literature (Chappuis et al., 2009; Olivier \& Hipp, 2006; Rodrigues-Campos et al., 2005; Wegenke, 2000). Their attitude and commitment to PD also serve as an example for other role players to continue their own learning. As regard constructive theories, the principal acknowledged that PD needs to be closely linked to the context of the school and that development occurs over time (Chalmers \& Keown, 2006; Hodkinson \& Hodkinson, 2005). Social constructivism also illuminates developmental foundations of the principal's practice and the interaction between the principal's developmental capacity and his engagement in school practice. This also explains why he selects staff to attend specific non-depart- 
mental PD programmes, a timetable for PD is set and the school budgets for PD each year. The principal's commitment and attitude towards personal growth and the growth of the school is explicitly explained in the way he led the school to become an inviting school.

\subsection{The head start: receiving the inviting school award}

The school received the prestigious Inviting School Award from The International Alliance for Invitational Education in 1993 (Fig. 1). A concerted effort by means of a number of PD sessions to staff members and other role players was required to initially introduce the Invitational Education (IE) approach. For the sake of its maintenance, continuous follow-up PD programmes on IE and related topics have been conducted at the school.

\section{Figure 1}

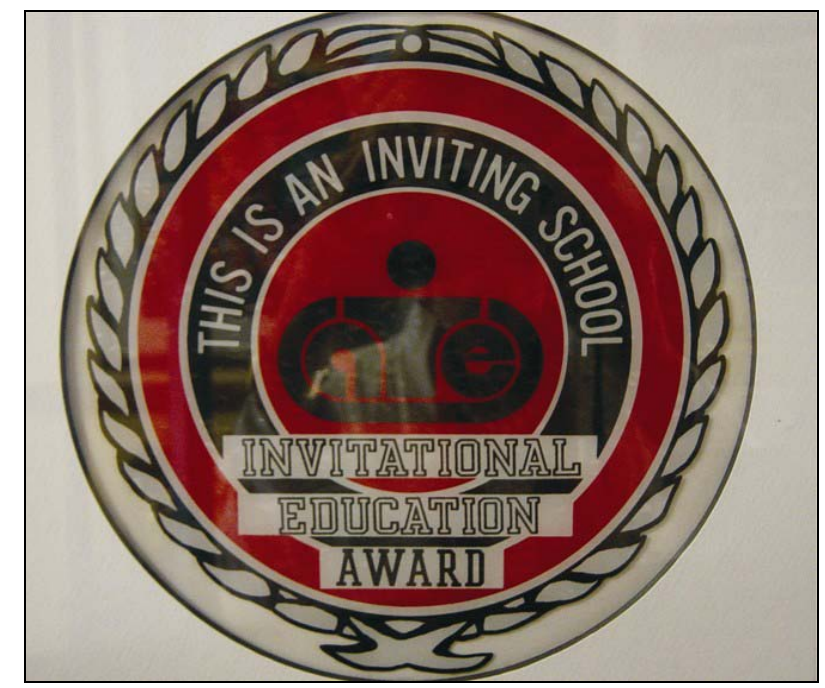

According to the principal, this was extremely encouraging and gave them a head start. "The award is like being lowered into starting blocks. It's what you do with the award afterwards that makes the difference." For him one of the important things for the "race" towards continuous improvement is to constantly learn from schools of excellence throughout the world. Throughout the interview the principal referred to the many changes that had taken place since the school received the inviting award (some discussed in this article). Although humble, he is very proud of all these achievements.

Egley (2003) believes that the influence of principals on education is greater than the influence of any other factor. Leadership permeates all levels of schooling and has a positive (or negative) effect by creating an environment conducive to teaching and learning (Card- 
no, 2005; Chappuis et al., 2009). Under the leadership of the principal, the school in the study has succeeded in sustaining the inviting culture in the school since 1993 (Steyn, 2006). As regard constructive theories, the principal and staff succeeded in acquiring new knowledge, skills and approaches, in particular that of IE, and to interpret their meaning and significance within the school situation (Chalmers \& Keown, 2006; Wenger, 2007; Hodkinson \& Hodkinson, 2005).

A school principal can therefore influence the climate of a school and can have a significant effect on the overall culture of a school. The $\mathrm{B}+$ climate of the school serves as another example to explain the culture of the school.

\subsection{Be positive $(\mathrm{B}+)$}

About eight years ago the principal arranged a training programme for staff at the school.

Professor Eugene Cloete, currently Dean of the Faculty of Natural Sciences at Stellenbosch, was the presenter. His whole approach was so positive in nature, on our country, education. His total stance as human being was catching. It made us realize to make that the aim of the school's point of departure, Be Positive (B+). (Fig. 2).

The principal admitted that unfortunately he often experiences difficulties with inculcating this positive approach, since the "people of our time are fairly negative about things".

\section{Figure 2}

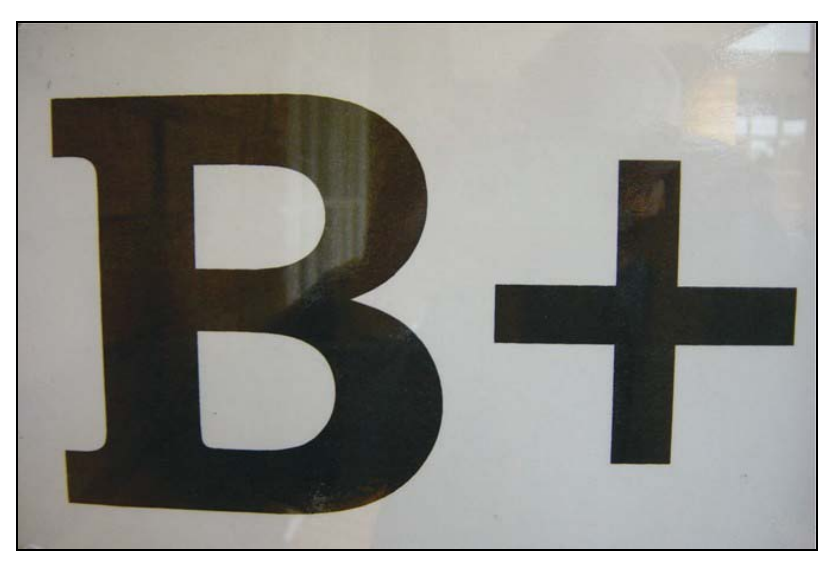

Professor Cloete also offered other presentations at the school and "he was very positive about everything that he presented". On one occasion when the principal accompanied Cloete to his car after one 
of his presentations, the principal asked him if there was anything that ever bothered him. "Professor Cloete did not even answer me." This motivated the principal to become even more positive. As a result of this, the principal put up a number of $B+$ signs in the school. "I do think that it helps here and there to make people positive." Moreover, this was the beginning of his attempt to influence the attitudes of all role-players at the school: "I spent a year trying to change the attitudes of people." During that year he read a lot about attitudes and every week he wrote something on attitude in their school's newsletter. During the course of the year, he also gave many talks to staff, learners and even parents on the effect of attitude. The principal showed me the powerpoint presentations of a number of these workshops. In summary he said, "Attitudes can change your whole life ... A great attitude produces a lot in life."

The principal referred to the importance of a principal's positive attitude to others. It should be obvious that a principal cares for others.

In the private sector they are focused on production. But people need to be happy at a place; staff should be happy; children should be happy. Organisations pay too little attention to people and therefore the production is not good enough ... One could ask the question: Is it about people or products?

Inculcating a $\mathrm{B}+$ atmosphere in the school shows that human beings do not live in a vacuum, but are embedded in a particular socio-cultural context (Paavola et al., 2004). Furthermore, the development of such a culture indicates that its development is strongly linked to the actual context of the school (Chalmers \& Keown, 2006; DarlingHammond \& Richardson, 2009:47). The findings also support the externalisation aspect in the study of Reeves et al. (2005) that shows how the principal, staff and learners in their interaction used the $\mathrm{B}+$ concept to bring change in their school environment (Olivier \& Hipp, 2006; Chappuis et al., 2009).

As mentioned before, leadership plays a key role in creating a positive teaching and learning environment. The positive school climate where people want to be and where everybody is happy also implies a focus on serving people in the school.

\subsection{A focus on client service}

The school's focus on clients was revealed in a number of ways: doing more than is expected, the blue and orange card system for 
learners, and inculcating a value system. All these aspects were the result of different PD programmes to focus on clients in the school.

\subsubsection{Doing more than is expected}

In his writings, the principal indicated how Professor Cloete emphasised the value of a focus on clients in the school. Cloete mentioned, among other things, that one should not merely offer a visitor a cup of tea or coffee, but provide a biscuit with it as well - implying that one should always do more than is expected of you. This single comment inspired the principal and the staff so much that they attended more programmes on client service, and staff members were trained accordingly. One of the workers has taken the initiative and places flowers in a vase whenever she serves a tray of tea or coffee to administrative staff in the school (Fig. 3).

\section{Figure 3}

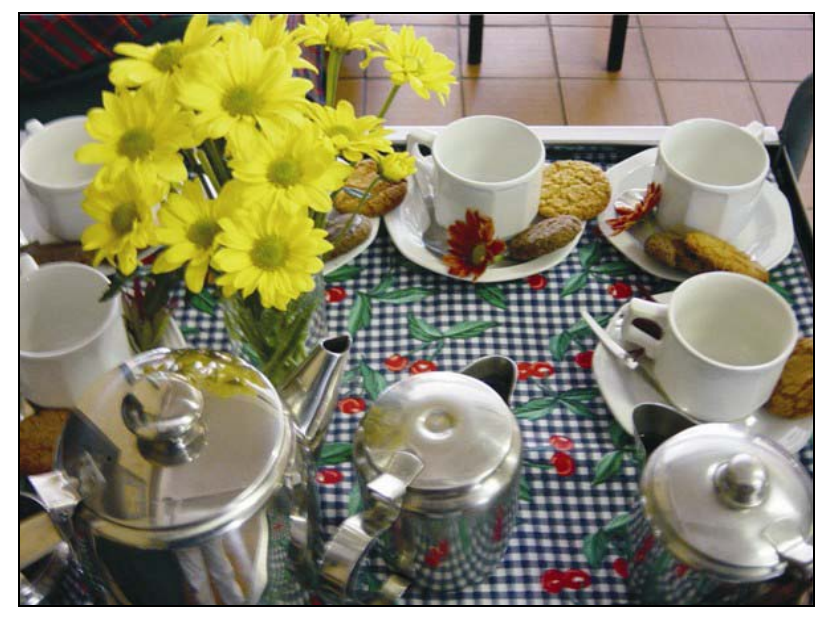

On the day of my first visit to the school for the new study, two learners welcomed me at the gate and guided me to my parking spot where a note bearing my name was attached to the pole. On my arrival, I also received a gift from the learners who then accompanied me to the principal's office. When I commented on these welcoming efforts the principal explained: "All strangers or visitors should be cared for and they need to be welcomed."

The findings show how the principal as adult is self-directed and has taken responsibility for developing staff towards a client focus (Knowles, 1984). Staff as adult learners on the other hand, accepted that this approach - client focus - is of immediate significance and value. The literature also confirms that every educational output has clients and quality is unlikely to improve without our recognising this 
(Kayser, 2003:173). In terms of quality management a client-focused organisation's primary goal involves determining who the client is and seeking to meet and exceed the client's needs (De Bruyn, 2003). The client-focus is also exemplified by the reward system for learners, the internal clients of the school.

\subsubsection{The blue and orange card system for learners}

This blue and orange card system, basically a reward system, is based on the invitational education approach, an example of a PD programme. William Purkey, the co-founder of Invitational Education, introduced the blue and orange card system (Paxton, 2003) (Fig. 4). According to Purkey, blue cards carry a message that a person is able, valuable and responsible whereas orange cards inform the person that he/she is unable, worthless and irresponsible. Any positive action or behaviour of a learner is indicated on the blue side of the card. In this study, the school's approach to acknowledging and rewarding people was also motivated by a friend of the school after his visit to Disneyland. This friend noticed how employees put their awards on their office walls and how proud they were of them. The principal calls it the Disneyland reward system (Fig. 5).

Figure 4

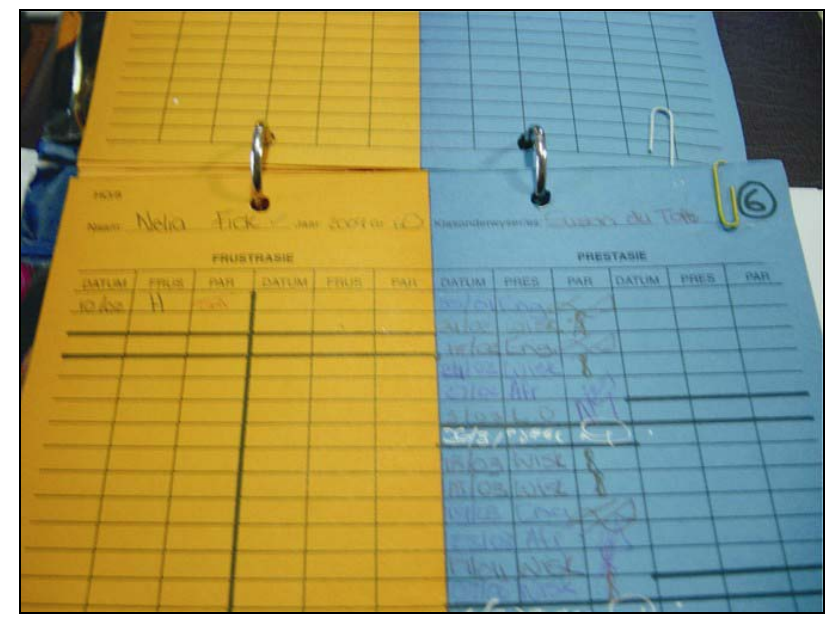




\section{Figure 5}

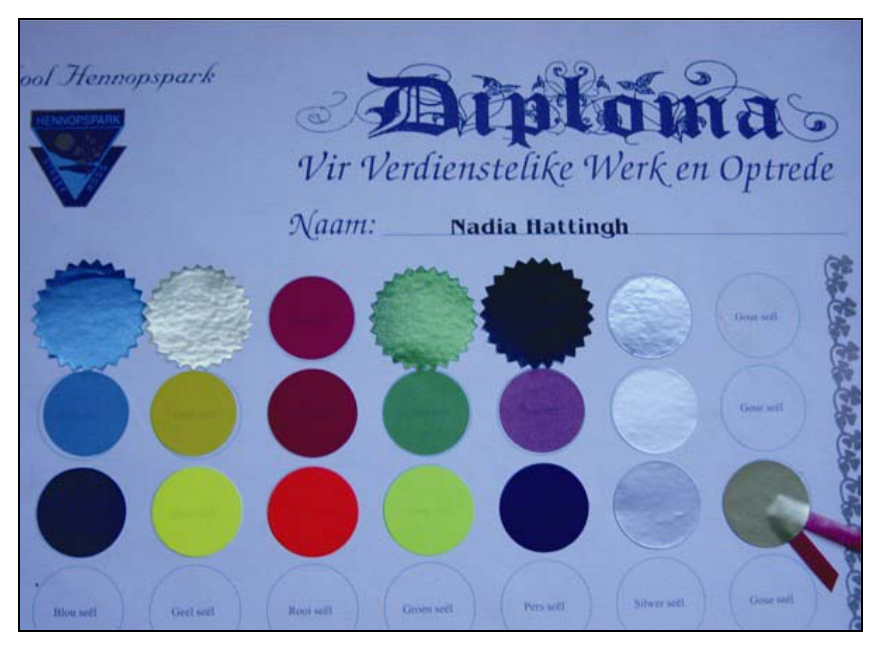

Previously the school used a black file system at the school and "we just worked very hard". In this file all the transgressions of children were recorded. The school totally moved away from that system and introduced the blue and orange card system. The principal ascribed the shift to the reinforcement of positive behaviour:

We could not flourish on such a negative thing, and it cannot work - especially when children see punishment in such a negative light ... If one looks at the whole file now, you see that most of the entries are positive. There are very few on the orange side. Between 96 and 97 percent of children have entries only on the blue side. The children work for them. Everyone wants a pat on the back, even me - and I am 65 years old.

Learners receive a stamp on a diploma for six blue entries on their blue and orange card. After six stamps they receive a certificate for their outstanding performance. After the seventh stamp, parents receive a letter to congratulate them on the noteworthy distinction their child has attained. The principal explained this system in this writings: learners can cancel a negative comment (orange), by accumulating six positives comments (blue). They still need to accumulate a total of six blue comments to receive a stamp. According to him the system works excellently, since learners are very positive about working for their stamps. On Fridays there are opportunities for learners to bring their blue and orange cards to the principal for his signature. In order to implement this reward system it required the necessary training of staff. All new staff members are also introduced to this award system. 
The positive reinforcement theory of motivation is one of the best ways of influencing and modifying people's behaviour in the right way (Anon., 2009; Champoux, 2000; Gerson \& Gerson, 2006; Prinsloo, 2003). The theory is based on the law of effect: those activities that are met with enjoyable consequences tend to be repeated, while those activities that are met with unpleasant consequences will probably not be repeated.

To reward learners for their achievements is noble, but it should not be at the expense of a particular value system.

\subsubsection{Inculcating a value system}

The idea of the "fruit of the spirit" comes from a parent in the school. Figure 6 reveals the "fountain of love". The following words, which are translated for the purpose of this figure, appear on the board next to it: Hennopspark - the school where God reigns. Words fountain that gives life. The principal explained:

It is extremely important to inculcate values in the children, values like love, friendliness, humility, neatness. These values are also part of the school programme and are inculcated during the life-skills period. People become so focused on the academics that they neglect their values. Take for example Nelson Mandela who was an excellent leader with an extremely strong and noble value system. Then you get other leaders without any value systems. At the core of many things is a value system: pride, respect, love, humility. It is for that reason that our school is so focused on values. The value system should prepare learners for a successful place in society. Even at prize-giving ceremonies learners receive awards for values that they show, like friendliness or diligence, or good manners or neatness. We give awards for that ... You should work with children to help them feel that they are valuable. I also want to empower the child. Children will become the leaders of tomorrow. 


\section{Figure 6}

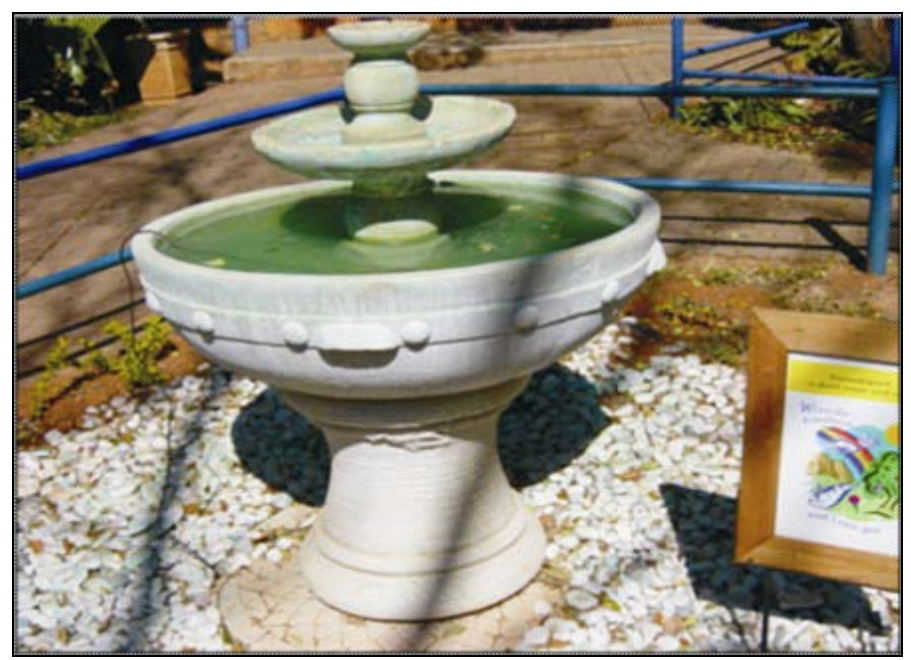

Another way in which the school shows its commitment to inculcating a value system is the report given to learners in the third term (Fig. 7). This report does not include any academic, cultural or sports achievements, but reflects the dignity and self-worth of each child (Steyn, 2006). The principal explained:

During the third term learners do not receive any academic reports. They receive a hand-written report from the teacher on all their positive characteristics. Each teacher only gives an account of the good qualities of the learner. This idea originated in a class in America.

The teacher requested learners to write a positive comment about every other child in the class. She then collected each child's comments and gave them to him/her. During the Vietnam war one of the soldiers who had been in her class was killed and when they emptied his pockets they discovered the crumpled report that his teacher and fellow classmates gave him many years ago. It was then that the principal realised actually how "few good things we say to each other". 
Figure 7

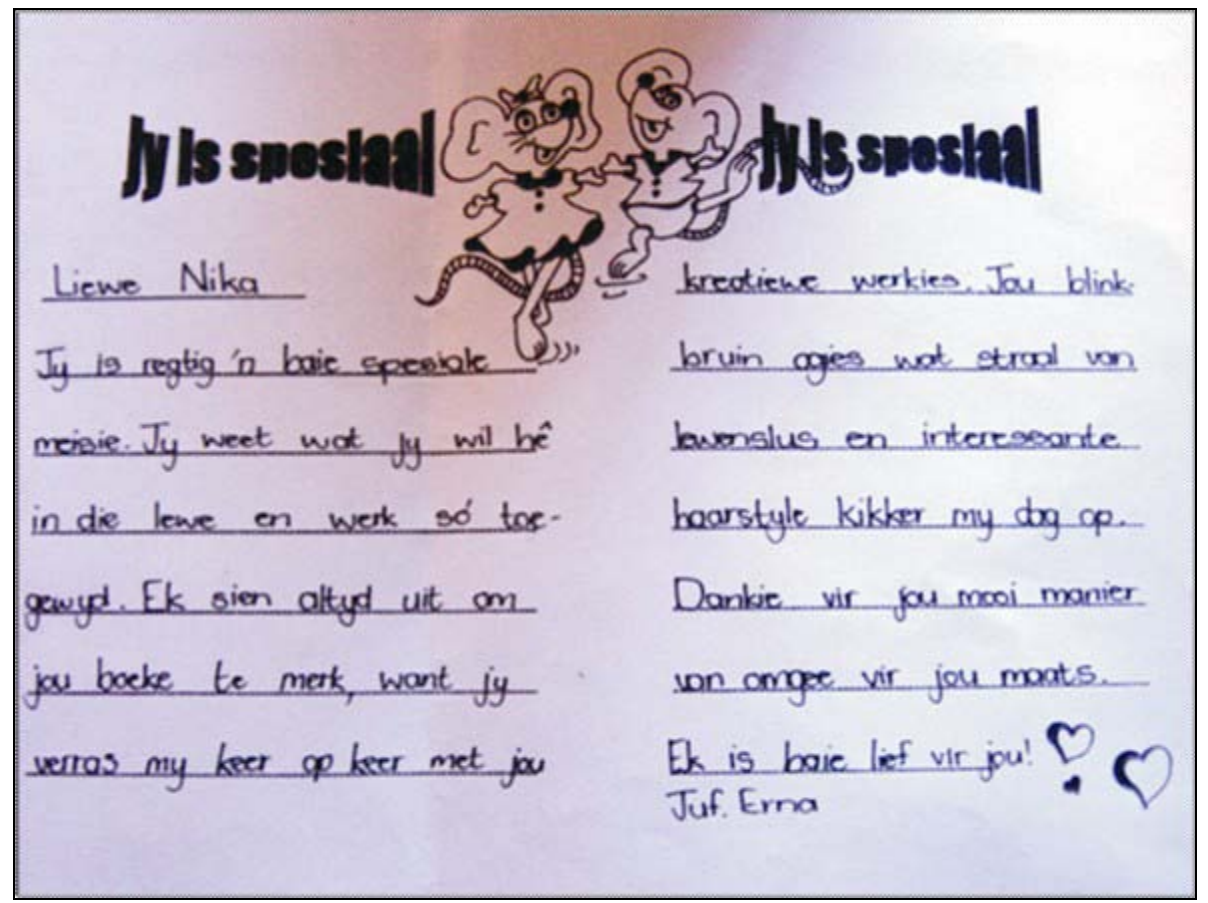

The importance of inculcating values is also supported by invitational education (Kok \& Van der Merwe, 2002; Purkey \& Siegel, 2003). People are able, valuable and responsible and should therefore be treated accordingly. By accepting such values, staff as adult learners show that the approach is meaningful and they are willing to take responsibility to implement them in practice (Knowles, 1984). Apart from the focus on the client, the school has accepted the challenge to constantly do things differently.

\subsection{What do we do differently?}

In his writings on doing things differently and comments on continuous improvement, the principal wrote:

In 2007 I attended a conference led by Professor Gideon Maas on futuristic trends and modern principles of management. Among the things he said was that businesses (practices) that do not think differently will be on the downgrade. This challenged us to devote 10 minutes each week to talk about new schools of thought. This is a standing item on our agenda. This compels us to constantly think innovatively. If you do what you always did, you will get what you always got (probably less).

He added that continuous change and development is necessary for a school to prosper. In 2008 his presentation to prospective grade 
one parents was based on the principles of what the school does differently from other schools. "We had one of the best enrolments ever." A DVD was also made (and is constantly adapted) as a result of doing things differently. The following words on the DVD which are translated for the purpose of this figure appear on it: "In Hennops' footsteps: the barefoot-fun-performance school."

Once a school has received the honour of attaining the prestigious IE award, it becomes increasingly important to continue demonstrating what it means to be inviting. Moreover, change in organisations is inevitable. According to Van der Merwe (2003:44) it is the principal's task "to initiate, facilitate and implement change". In accordance with constructivist theories, the findings reveal that new developments and change take time to be implemented successfully (Chalmers \& Keown, 2006; Darling-Hammond \& Richardson, 2009; Hodkinson \& Hodkinson, 2005). The principal's response to the importance of continuous development is also supported in the literature (Crum \& Sherman, 2008; Gokçe, 2009; Richardson, 2003). Throughout the photo-elicitation interview it became clear that this principal has a definite stance on PD. He also explicated some guidelines for the effective implementation of PD.

\subsection{Guidelines for implementing professional development effectively}

On the question of what guidelines the principal would recommend for the effective implementation of $P D$, he made three suggestions.

- The principal's commitment and attitude to PD is very important.

I'll begin with myself. If I do not have fire in my heart, I will not be able to transfer it to others. In order to empower others, you have to empower yourself. I attended courses and read at least 10 minutes per day as is recommended ... You have to keep abreast in the world. There is an unbelievable amount of material and research available. You simply cannot stay behind. It [PD] begins with yourself.

- Once the principal him-/herself is empowered, the next step is to "look at the people around you, their development and their happiness".

- Finally the principal explained the importance of learners. The main aim of professional development should be the well-being of learners and the improvement of their performance as he explained: 
The primary client is the child ... We should look more at the child. Children should be happy. Many people only think about themselves and do not take the children into consideration. It is always important to think carefully before decisions are made: Is the decision in my interests or the children's? You cannot ignore the children in decisions. I am now taking my courage in both hands when I talk about primary schools where learners are dressed as if they are going to church, with cheese cutters and blazers, et cetera. This is an excellent illustration of thinking about oneself - not about children. Children want to dress in what they feel comfortable in ... Children want to go barefoot; they want to play. I am, however, still in favour of neatness.

The guidelines for PD reflect the fact that the principal learnt through experience (Knowles, 1984) and that he has been searching for an understanding of the world in which he lives and works (Creswell, 2007; Drago-Severson, 2007). As a result he has developed subjective meanings of his experiences regarding PD (Creswell, 2007).

\section{Conclusion}

Although they provide insight, many data-collecting methods are inadequate to produce the depth of information required to measure the impact of PD programmes. Using reflexive photography to study the impact of a principal's perceptions of PD on a school has shed additional light on the development of meaning that the principal ascribes to his perceptions and experiences through and as a function of his social interaction within the school (Harrington \& Schibik, 2003:36). The photos that the principal took symbolise the significance and interpretation of the principal's interaction with his social and physical environment. This technique has provided authentic examples of what impact a principal's PD and his commitment and attitude to PD can have on a school. This information is presented in both the participant's pictures and his words. They also reveal the importance of principals' positive attitude towards their own PD and the PD of their staff for the sake of continuous school development and improvement.

Finally, the requirement of the ever-changing character of principalship is that principals constantly need to update their knowledge and skills to assist their schools to face new challenges. The core objective of the professional programmes for educational leaders should be to promote high quality learning among all learners in the schools (Kent, 2002). This implicates that principals need to understand current approaches to learning and engage the staff in 
continuously developing their approach to teaching and learning (Rodrigues-Campos et al., 2005:311).

\section{List of references}

AMEY, M.J. 2005. Leadership as learning: conceptualizing the process. Community college journal of research and practice, 29(9 \& 10):689-704.

ANON. 2009. Education letter, July 8, Atlanta: 31. http://0-proquest.umi.com. oasis.unisa.ac.za/pqdweb?index $=0 \&$ did $=1771244101 \&$ SrchMode $=2 \&$ sid $=$ $2 \& F m t=3 \& V I n s t=P R O D \& V T y p e=P Q D \& R Q T=309 \& V N a m e=P Q D \& T S=124$ $6860441 \&$ clientld=27625 Date of access: 10 Jul. 2009.

ATKINSON, P. \& DELAMONT, S. 2008. Analytic perspectives. (In Denzin, N.K. \& Lincoln, Y.S., eds. Collecting and interpreting qualitative materials. 3rd ed. Thousand Oaks: Sage. p. 285-311.)

BERNAT, E. 2000. Attending to adult learners: affective domain in the ESL classroom. www.hltmag.co.uk/sept04/mart02.rtf Date of access: 10 Mar. 2009.

BERRY, M.A.R. 2004. Succession to school leadership: challenge and response for principals: record of study, doctor of education. Office of Graduate Studies of Texas A\&M University. http://txspace.tamu.edu/ bitstream/1969.1/418/1etd-tamu-2004A-EDAD-Berry-1.pdf Date of access: 4 Jul. 2006.

BLOCH, G. 2008. SA in the midst of an education crisis. The Star: 19, 31 Jul.

BRUNDRETT, M. 2000. The question of competence: the origins, strengths and inadequacies of a leadership training paradigm. School leadership \& management, 20(3):353-369.

CARDNO, C. 2005. Leadership and professional development: the quiet revolution. International journal of educational management, 19(4):292306.

CHALMERS, L. \& KEOWN, P. 2006. Communities of practice and professional development. International journal of lifelong learning, 25(2):139-156.

CHAMPOUX, J.E. 2000. Organizational behavior: essential tenets for a new millennium. Cincinnati: South-Western College Publishing.

CHAPPUIS, S., CHAPPUIS, J. \& STIGGINS, R. 2009. Supporting teachers. Educational leadership, 66(5):56-60.

CRESWELL, J.W. 2007. Qualitative inquiry and research design: choosing among five approaches. 2nd ed. Thousand Oaks: Sage.

CRUM, K.S. \& SHERMAN, W.H. 2008. Facilitating high achievement: high school principals' reflections on their successful leadership practices. Journal of educational administration, 46(5): Abstract. http://0-proquest. umi.com. oasis.unisa. ac.za/pqdweb?index $=1 \&$ did $=1548666161 \&$ SrchMode $=2 \&$ sid $=5 \& F m t=2 \& V I n s t=P R O D \& V T y p e=P Q D \& R Q T=309 \& V N a m e=P Q D \&$ TS=1246872352\&clientld=27625 Date of access: 6 Jul. 2009.

DARLING-HAMMOND, L. \& RICHARDSON, N. 2009. Teacher learning. Educational leadership, 66(5):46-53.

DAY, C., HARRIS, A. \& HADFIELD, M. 2001. Grounding knowledge of schools in stakeholder realities: a multi-perspective study of effective school leaders. School leadership \& management, 21(1):19-42. 
DE BRUYN, P.P. 2003. A management strategy for the improvement of the effectiveness of secondary schools through total quality management. Potchefstroom: PU for CHE. (Ph.D. thesis.)

DELL, D. 2003. Revisiting adult education theories: can emancipatory learning begin to redress the shortfall in achieving learning organizations? p. 1-8. http://www.edu.edu.au/conferences.tlf/2003/pub/pdf/16DennisDell.pdf Date of access: 15 Aug. 2008.

DENZIN, N.K. \& LINCOLN, Y.S. 1994. Introduction: entering the field of qualitative research. (In Denzin, N.K. \& Lincoln, Y.S., eds. Handbook of qualitative research. 3rd ed. Thousand Oaks: Sage. p. 11-17.)

DENZIN, N.K. \& LINCOLN, Y.S. 2008. Methods of collecting and analyzing empirical materials. Part 1. (In Denzin, N.K. \& Lincoln, Y.S., eds. Collecting and interpreting qualitative materials. 3rd ed. Thousand Oaks: Sage. p. 45-55.)

DONALDSON, G.A. 2009. The lessons are. Educational leadership, 66(5):1418.

DRAGO-SEVERSON, E. 2007. Helping teachers learn: principals as professional development leaders. Teachers college record, 109(1):70-125.

EGLEY, R. 2003. Invitational leadership: does it make a difference? Journal of invitational theory and practice, 9:57-70.

ENGESTROM, Y. 1987. Learning by expanding. Helsinki: Orienta-Konsultit Oy.

FENNELL, H-A. 2005. Living leadership in an era of change. International journal of leadership in education, 8(2):145-165.

GERSON, R.F. \& GERSON, R.G. 2006. $T+D$ (Training and development), 60(6):26-27. http://0-proquest.umi.com.oasis.unisa.ac.za/pqdweb?Index $=2 \&$ did $=1061991131 \&$ SrchMode $=2 \&$ sid $=2 \& F m t=2 \& V I n s t=P R O D \& V T y p e=$ PQD\&RQT=309\&VName=PQD\&TS=1246860441\&clientld=27625 Date of access: 6 Jul. 2009.

GOKÇE, F. 2009. Behaviour of Turkish elementary school principals in the change process: an analysis of the perceptions of both teachers and school principals. Educational management administration \& leadership, 37(2). http://0-proquest.umi.com.oasis.unisa.ac.za/pqdweb?index=0\&did= $1651768491 \&$ SrchMode $=2 \&$ sid $=4 \& F m t=2 \& V I n s t=P R O D \& V T y p e=P Q D \& R$ QT=309\&VName=PQD\&TS=1246871975\&clientld=27625 Date of access: 6 Jul. 2009.

GONZALES, M., GLASMAN, N. \& GLASMAN, L.D. 2002. Daring to link principal preparation programmes to student achievement. Leadership and policy in schools, 1(3):265-283.

GRACZEWSKI, C. \& HOLTZMAN, D.J. 2009. Instructional leadership in practice: what does it look like, and what influence does it have? Journal of education for students placed at risk, 14(1):72.

GRAY, S.L. 2005. An enquiry into continuing professional development for teachers. University of Cambridge: Esmee Fairbairn Foundation.

HALE, E.L. \& MOORMAN, H.N. 2003. Preparing school principals: a national perspective on policy and programme innovations. http://www.iel.org/pubs/ PreparingSchoolPrincipals.html Date of access: 5 Jul. 2006.

HAMMERSLEY-FLETCHER, L. \& BRUNDRETT, M. 2005. Leaders on leadership: the impressions of primary school head teachers and subject leaders. School leadership and management, 25(1):59-75. 
HARPER, D. 2008. What's new visually? (In Denzin, N.K. \& Lincoln, Y.S., eds. Collecting and interpreting qualitative materials. 3rd ed. Thousand Oaks: Sage. p. 185-204.)

HARRINGTON, C.E. \& SCHIBIK, T.J. 2003. Reflexive photography as an alternative method of the study of freshman year experience. National Association of Student Personnel Administrators (NASPA) journal, 41(1):23-40.

HESS, F.M. \& KELLY, A.P. 2005. Learning to lead? What gets taught in principal preparation programmes. http://www.ksg.harvard.edu/pepg/ PDF/Papers/Hess_Kelly_Learning_to_Lead_PEPG05.02.pdf Date of access: 5 Jul. $200 \overline{6}$.

HIRSH, S. 2005. Professional development and closing the achievement gap. Theory into practice, 44(1):38-44.

HODKINSON, H. \& HODKINSON, P. 2005. Improving schoolteachers' workplace learning. Research papers in education, 20(2):109-131.

HOULE, J.C. 2006. Professional development for urban principals in underperforming schools. Education and urban society, 38(2):142-159.

HOY, W.K. \& SMITH, P.A. 2007. Influence: a key to successful leadership. International journal of educational management, 21(2):158-167.

JABAL, E. 2006. Learning from Hong Kong alumni: lessons for school leadership. International journal of leadership in education, 9(1):21-44.

KASSISSIEH, J. \& BARTON, R. The top priority teacher leadership. Principal leadership, 9(7):22-26. (High school edition.) http://0-proquest.umi.oasis. ac.za/pqdweb?index=2\&did=1663258271\&Src Date of access: 22 Jun. 2009.

KAYSER, K. 2003. Using total quality management tools in human service intervention research. Journal of social work research and evaluation, 4(2):171-187.

KENT, P. 2002. The professional development of principals: innovations and opportunities. Educational administration quarterly, 38(2):213-232.

KINNEY, P. 2009. Instructional practices. Principal leadership, 9(7):48-51. (High school edition.) http://0-proquest.umi.oasis.ac.za/pqdweb?index=9\&did= 1663258321\&Src Date of access: 22 Jun. 2009.

KNOWLES, M. 1984. The adult learning: a neglected species. 3rd ed. Houston: Gulf.

KOK, J.C. \& VAN DER MERWE, M.P. 2002. Invitational education: adding uniqueness - an empirical study. Paper presented at the 18th International Conference of the IAIE, October 10-12 2002, Kennesaw State College, Atlanta.

LEASE, A.J. 2002. New administrators need more than good grades. School administrator, 59(6):40-41.

LEE, H.L. 2005. Developing a professional development programme model based on teachers' needs. The professional educator, 27(1 \& 2):39-49.

LEVINE, A. 2005. Educating school leaders: the education schools project. www.edschools.org/pdf/Final313.pdf Date of access: 3 Jul. 2006.

LIN, J. 2005. Perception of principals in the Southern, urban U.S. and Eastern, urban China regarding the selection, preparation, and professional development of elementary principals. https://txspace.tamu.edu/bitstream/ 1969.1/2563/1/etd-tamu-2005B-EDAD-Lin.pdf Date of access: $5 \mathrm{Jul}$. 2006. 
MAHONEY, M.J. 2003. Constructivism growing. Copy of handout distributed at the 8th International Congress of Constructivism, Bari, Italy, June, 2003. http://www.homerweb.com/cache.html?a=cachedContent\&id=315960\&a2= web Date of access: 25 Jun. 2009.

MCCLAY, M. \& BROWN, M. 2003. Using concept mapping to evaluate the training of primary school leaders. International journal of leadership in education, 6(1):73-87.

MCKERROW, K., DUNN, R. \& KILLIAN, J. 2003. Beyond the turf wars: collaboration in preparing school leaders. Education leadership review, 4(1):1-10.

MEADOWS, K.A. 2003. So you want to do research? An overview of the research process. British journal of community nursing, 8(8):369-375.

MESTRY, R. \& GROBLER, B.R. 2004. The training and development of principals to manage schools effectively using the competence approach. ISEA, 32(3):2-19.

NOVAK, J.M. \& PURKEY, W.W. 2001. Invitational education. Bloomington: Phi Delta Kappan Educational Foundation.

OLIVIER, D.F. \& HIPP, K.K. 2006. Leadership capacity and collective efficacy: interacting to sustain student learning in a professional learning community. Journal of school leadership, 16(5):505-519.

PAAVOLA, S., LIPPONEN, L. \& HAKKARAINEN, K. 2004. Models of innovative knowledge communities and three metaphors of learning. Review of educational research, 74(4):557-576.

PATON, C. 2006. Education in crisis: a lot to learn. Financial mail: 1, 8 Sept.

PAXTON, P. 2003. Inviting e-learning: how hard can it be? Journal of invitational theory and practice, 9:23-40.

PRINSLOO, I.J. 2003. Leadership and motivational skills. (In Van Deventer, I. \& Kruger, A.G. 2003. An educator's guide to school management skills. Pretoria: Van Schaik. p. 139-155.)

PURKEY, W.W. \& NOVAK, J.M. 2008. Fundamentals of invitational education. Kennesaw: Kennesaw State University.

PURKEY, W.W. \& SIEGEL, B. 2003. Becoming an invitational leader: a new approach to professional and personal success. Atlanta: Humanics Trade Group.

REEVES, J., TURNER, E., MORRIS, B. \& FORDE, C. 1998. Developing a model of practice: designing a framework for the professional development of school leaders and managers. School leadership \& management, 18(2):185-196.

RICHARDSON, V. 2003. The dilemmas of professional development. Phi delta kappan, 84(5):401-406.

RODRIGUES-CAMPOS, L., RINCONES-GOMEZ, R. \& SHEN, J. 2005. Secondary principals' educational attainment, experience, and professional development in USA. International journal of leadership in education, 8(4):309-319.

SCHULZE, S. 2007. The usefulness of reflexive photography for qualitative research: a case study in higher education. South African journal of higher education, 21(5):536-553.

SMITH, C. \& GILLESPIE, M. 2007. Research on professional development and teacher change: implications for adult basic education. http://www.ncsall. net/fileadmin/resources/ann_rev/smith-gillespie-07.pdf Date of access: 21 Aug. 2008. 
SOUTHWORTH, G. \& DU QUESNAY, H. 2005. School leadership and system leadership: essays. The educational forum, 69(2):212-220.

STERNBERG, R.J. 2005. A model of educational leadership: wisdom, intelligence, and creativity, synthesized. International journal of leadership in education, 8(4):347-364.

STEYN, G.M. 1994. Die sigbaarheid van die skoolhoof as bestuursbenadering: 'n gevallestudie. Onderwysbulletin, 2(38):16-31.

STEYN, G.M. 2008. Aspects influencing the implementation of continuing professional development for South African teachers. Third International Conference on Interdisciplinary Social Science, Monash University, Prato, Italy, 22-25 July 2008.

STEYN, G.M. 2009. Teachers' perceptions of the provision of continuing professional development programmes in South Africa: a qualitative study. Accepted for publication in Acta Academica.

STEYN, T. 2006. Sustaining an inviting culture in a South African school: a case study. Journal of educational studies, 5(1):1-15.

VAN DER MERWE, H.M. 2003. Organisational change. (In Van Deventer, I. \& Kruger, A.G. 2003. An educator's guide to school management skills. Pretoria: Van Schaik. p. 37-48.)

VICK, R.C. 2004. The use of SREB leadership development framework in preservice preparation programs: a qualitative study. Dissertation, Department of Educational Leadership and Policy Analysis, East Tennessee State University. http://etd-submit.etsu.edu/etd/theses/ available/etd-0809104-151312/unrestricted/VickR081904f.pdf Date of access: 5 May 2009.

WEGENKE, G. 2000. Principals' role in school restructuring in the Des Moines public schools. Education and urban society, 32(4):519-534.

WEINDLING, D. 2003. Leadership development in practice: trends and innovation. http://www.ncl.org/uk/media/1D4/DD/leadership-developmentin-practice-trends-and-innovations.pdf Date of access: 10 Jul. 2009.

WENGER, E. 2007. Communities of practice. Third Annual National Qualifications Framework Colloquium, Velmore Conference Estate.

YU, H., LEITHWOOD, K. \& JANTZI, D. 2000. The effects of transformational leadership on teachers' commitment to change in Hong Kong. Journal of educational administration, 40(4):368-389.

ZENKOV, K. \& HARMON, J. 2009. Picturing a writing process: photovoice and teaching writing in urban youth. Journal of adolescence \& adult literacy, 52(7):575-584.

\section{Keywords:}

invitational education

professional development

reflexive photography

visual ethnography 


\section{Kernbegrippe:}

professionele ontwikkeling

refleksiewe fotografie

uitnodigende onderwys

visuele etnografie 
